\title{
Nordenskiöld or Nordenskjöld?
}

\author{
A. K. Higgins \\ Grønlands Geologiske Undersøgelse, Øster Voldgade 10, DK-1350 Kфbenhavn K, Danmark.
}

The Nordenskiöld Bjerg Subgroup takes its name from Nordenskiöld Bjerg in Canning Land, East Greenland, but the mountain takes its name not from A. E. Nordenskiöld or his son G. E. A. Nordenskiöld, but from Otto Nordenskjöld. All were Swedish scientists, commemorated by place names in Greenland. The features named after them, however, have been variously spelt due to uncertainty as to which of them was being honoured, and also variations in orthographic practice.

Nordenskiöld Bugt, a bay on the east coast of Shannon, was named during the 1869-70 German expedition led by Koldewey (1873-74), originally in the form Nordenskjöld Bucht. This spelling occurs on all Koldewey's maps, but it is clearly intended to commemorate A. E. Nordenskiöld, whose name is also spelt 'Nordenskjöld' in German biographical works of the period (e.g. Poggendorff, 1863). At this time Nordenskiöld was already noted for his expeditions to Spitzbergen, in 1858, 1861 and 1868.

Nordenskiöld Gletscher is a major glacier at the head of Kejser Franz Joseph Fjord, named Nordenskiölds Glacier by A. G. Nathorst for A. E. Nordenskiöld during his 1899 expedition. [Niels] Adolf Erik Nordenskiöld [1832-1901], to whom Nathorst dedicated the account of his expedition (Nathorst, 1900), had encouraged Nathorst to take up his studies of the fossil flora of Skane. In 1878-79 Nordenskiöld had completed his most celebrated Arctic voyage, through the North-East Passage in the Vega. In 1883 Nathorst was deputy leader on Nordenskiöld's last Arctic expedition to West Greenland. Incorrect variations in spelling include Nordenskjölds Gletscher and Nordenskiølds Gletscher.

Nordenskiöld $\emptyset$ is an island in the mouth of Vega Sund, the channel between Geographical Society $\emptyset$ and Traill $\varnothing$. Nathorst (1900) originally used the name Kap Nordenskiöld for a feature in the vicinity, which White (1927), with the advantage of sailing and surveying in the same waters, identified as an island; a comparison of relevant maps suggests (perhaps wrongly) that Nathorst might have intended the name for a feature near Kap McClintock. Nathorst does not specifically attribute this name to A. E. Nordenskiöld, and reasoning that he would not name two features after the same person during the same expedition, one might conclude that he intended to honour Nordenskiöld's son, Gustaf Erik Adolf Nordenskiöld [1868-95], an archaeologist and mineralogist; he led an expedition to Spitzbergen in 1890, and his important collections of fossils had been described by Nathorst. The latest edition of the 1:250 000 topographic map (Geodætisk Institut, 1974) uses the incorrect variation Nordenskjölds $\emptyset$.

Nordenskiöld Bjerg in Canning Land was named by Lauge Koch during his 1926-27 expedition as Mt. Nordenskiöld, to commemorate the important geological work in the region carried out by Otto Nordenskjöld, whose name Koch consistently spells 'Nordenskiöld'; Koch also named the Triassic 'Mount Nordenskiöld Formation' after the mountain (Koch, 1929). [Nils] Otto [Gustaf] Nordenskjöld [18691928], a Swedish geologist and oceanographer, and a nephew of A. E. Nordenskiöld, led expeditions to Greenland in 1900 and 1905, and the 1901-03 Swedish Antarctic expedition. Noe-Nygaard (1934) used the 'correct' spelling 'Nordenskjöld' for both the mountain and the geological formation in his geological description. However, Koch's spelling has survived and has been used in the literature for half a century. Perch-Nielsen et al. (1974) upgraded the stratigraphical division to the Nordenskiöld Bjerg Subgroup. The approved spelling of Nordenskiöld Bjerg should not be 'corrected' now.

In other parts of Greenland can be found: Nordenskiöld Fjord in North Greenland, Nordenskiöld Gletscher in Melville Bugt, North-West Greenland, another Nordenskiöld Gletscher in central West Greenland, and Nordenskiöld Næes in South-East Greenland; all were named for A. E. Nordenskiöld.

\section{References}

Geodætisk Institut, 1974: Grønland 1:250 000, 72 Ø.1 Kap Parry. København: Geodætisk Institut.

Koch, L. 1929: Stratigraphy of Greenland. Meddr Grønland 73, II (2), 205-320.

Koldewey, K. 1873-74: Die zweite deutsche Nordpolarfahrt in den Jahren 1869 und 1870 unter Führung des Kapitän Karl Koldewey, 699 \& 962 pp. Leipzig: F. A. Brockhaus.

Nathorst, A. G. 1900: Två somrar i Norra Ishavet, 352 \& 414 pp. Stockholm: Beijars Bokforlag.

Noe-Nygaard, A. 1934: Stratigraphical outlines of the area round Fleming Inlet (East Greenland). Meddr Grønland 103(1), $88 \mathrm{pp}$.

Perch-Nielsen, K., Birkenmajer, K., Birkelund, T. \& Aellen, M. 1974: Revision of Triassic stratigraphy of the Scoresby Land and Jameson Land region, East Greenland. Bull. Gronlands geol. Unders. 109, 51 pp.

Poggendorff, J. C. 1863: Biographisch-Literarisches Handwörterbuch zur geschichte der exacten Wissenschaften, 1583 \& 1467 pp. Leipzig: Johann Ambrosius Barth.

White, P. F. 1927: The Cambridge expedition to East Greenland in 1926. App. II. Place-names. Geogr. J. 70, $244-247$. 